\title{
Tendencies in development of energy assistance systems in an electric car
}

\section{ARTICLE INFO}

Received: 2 December 2021

Revised: 6 January 2022

Accepted: 11 January 2022

Available online: 14 February 2022
As awareness regarding ecology increases among drivers, some characteristics of electric vehicles mean that they attract a greater interest. The basic factors determining the demand for electric cars include their pricing, access to charging stations and the cost per $1 \mathrm{kWh}$. Considering the above, the aim of this paper is to review the current areas of research into renewable energy sources, such as wind and solar energy and energy derived from vertical displacements of the car body associated with road roughness. The use of such solutions will allow the battery to be charged while the vehicle is in motion and extend the time of travel without stopping the vehicle for charging. The publication forms an overview of findings in the area and the scope of the research reported here relate to the most recent research. For this purpose, reviews of academic and industrial literature were carried out.

Key words: electric cars, renewable energy, wind turbine, photovoltaic systems, regenerative shock absorber

This is an open access article under the CC BY license (http://creativecommons.org/licenses/BY/4.0/)

\section{Introduction}

Nowadays in the world, where carbon dioxide emissions and pollution form a major concern, electric cars are becoming more and more attractive. In comparison with cars running on petroleum-derived fuels, electric vehicles generate little or no greenhouse gases and air pollutants. As a result of the advances in the automotive technology, we have faced considerable progress in electric car design in recent years. Almost every major car maker in the world is now starting to develop fully electric models. In addition, due to incentives and campaigns customers are also attracted by the idea of using an electric car.

The Allied Market Research (AMR) [1] report, which provides a thorough analysis of the automotive market, reveals an exponentially growing demand for fuel-efficient, high-performance, low-emission vehicles. The report also contains a statement that the growth in this demand can be encouraged by restrictive government emissions regulations in many countries. On the other hand, technological advances and proactive government initiatives are providing the automotive market with exponential growth (Fig. 1). Allied Market Research is the market research and business consultation division of Allied Analytics LLP. AMR provides global enterprises as well as medium and small businesses with reports on market research and Business Intelligence solutions. Its role includes advice and support to their clients in making strategic business decisions in relevant market areas. In a report by this company [1], we can read that the global electric vehicle market is segmented by vehicle type, type and class, and region. By type, it is divided into Battery Electric Vehicle (BEV), Hybrid Electric Vehicle (HEV) and Plug-in Hybrid Vehicle (PHEV). According to vehicle type, it is classified into two-wheelers, passenger cars and commercial vehicles. Due to the class of the vehicle, it is divided into the mid-price and luxury class. By region, the market is analyzed in North America (United States, Canada and Mexico), Europe (Germany, France, UK, Netherlands, Norway and the rest of Europe), AsiaPacific (China, Japan, Singapore, South Korea and the rest of Asia Pacific) and LAMEA (Latin America, Middle East and Africa).The key players in the electric vehicle market include Tesla, BMW Group, Nissan Motor Corporation, Toyota Motor Corporation, Volkswagen AG, General Motors, Daimler AG, Energica Motor Company SpA, BYD Company Motors and Ford Motor Company.

The authors of the report indicate some of the advantages of electric cars that can play a decisive role on their attractiveness compared to cars with classic engines:

1. Electric vehicles are characterized by lower operating costs compared to traditional cars. Although the mechanical parts in an electric vehicle are expensive, the number of parts is smaller. This also reduces the risk of mechanical failure. In addition, regular maintenance required on conventional cars, including oil changes, fluid supplement and the supply of other consumables, is not required in electric vehicles. Although the need to replace the battery is the only big expense in electric vehicles, such cars offer sufficient mileage prior to the need to do so.

2. Electric vehicles are characterized by smaller pollutions than traditional cars as they do not emit exhaust gases. In addition, electric vehicles can be charged using renewable energy, sources which can further reduce greenhouse gas emissions. On the other hand, manufacturers are also taking initiatives for more environmentally friendly methods in manufacturing electric vehicles. Several companies use recycled and bio-based materials to produce electric vehicles.

3. Electric cars have a lower center of gravity which reduces the likelihood of a vehicle rolling over. The risk of fires and explosions is also reduced. Moreover, it is much quieter than a traditional car and more dynamic in city traffic due to the better torque characteristics of the electric motor.

Electric cars use batteries as their primary power source. However, an important disadvantage of electric cars is related to the significantly shorter range compared to the vehicles with classic ICEs. In city class cars, the range 
ranges from 100 to $120 \mathrm{~km}$, and in the case of top-of-therange cars, it is around $500 \mathrm{~km}$. Manufacturers try to solve this problem place in electric cars as large batteries as possible for the purpose of and possible additional energy generation and storage units [2]. Fortunately, intensive research is underway to develop batteries that will make electric cars more attractive [3]. China appears to be the first region to undertake a transition from conventional to electric vehicles, but its perspective in time is still uncertain. Europe is likely to be next, due to legal regulations and determination to fight climate change [4].

Electric cars (EVs) currently provide the best performance in terms of energy-efficiency (Fig. 2). Their efficiency ranges from $60 \%$ to $66 \%$ in the urban driving cycle. However, if this balance was to include the energy recovery from regenerative braking (converted after reuse), we find out that the efficiency of electric cars ranges from $86 \%$ to $94 \%$. For comparison, in a car with a conventional combustion engine (ICE) in urban driving conditions only $12-25 \%$ of the energy derived from fuel is used to drive the car. Most of the energy is lost by the internal combustion engine in the form of heat, frictional losses and ineffective combustion. In the urban driving cycle, hybrid cars have at their disposal $21-40 \%$ of energy derived from fuel and electrochemical battery $[5,6]$.

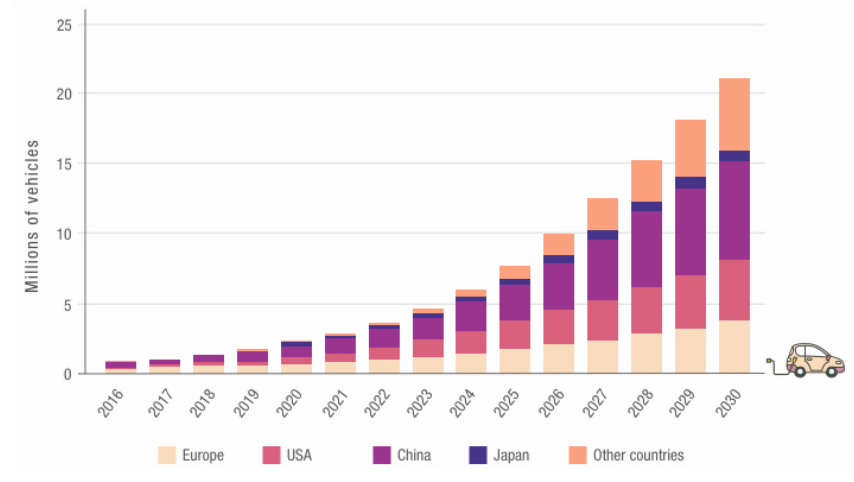

Fig. 1. Global growth of the electric vehicle market (Bloomberg New Energy Finance (BNEF))

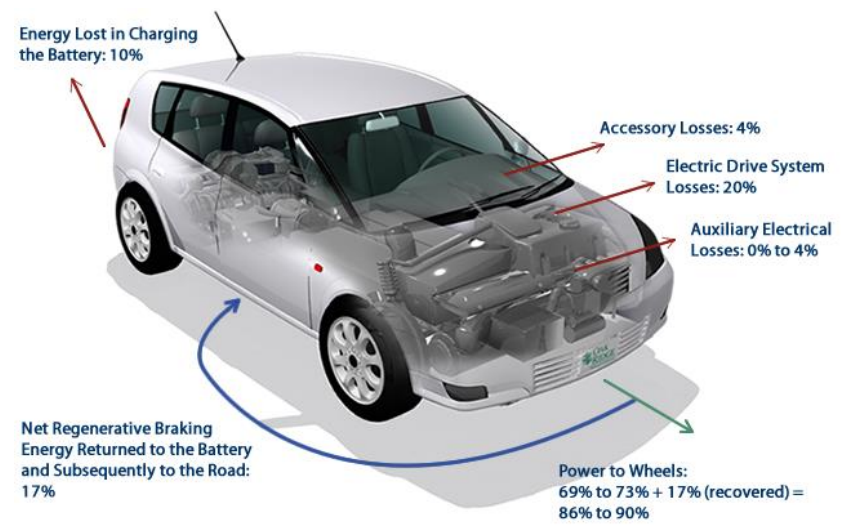

Fig. 2 Electric car energy requirements for combined City/Highway driving [5]

In an electric car, energy is employed for a variety of purposes. Most of the energy is used as the source of power to the wheels (as the energy of motion). A significant amount of energy is also delivered to power the auxiliary devices (lights, drive assistance systems, sound system, etc.). There are cooling and heating systems necessary to ensure proper operation of the powertrain system (electric motor, batteries).

We can assume that for most lithium-ion cells, the permissible operating temperature is in the range of $15-50^{\circ} \mathrm{C}$. Below this range, the battery is already operating with limited efficiency. However, when this temperature range is exceeded, the cell can be damaged. For this reason, producers of electric cars choose a cooling system that is appropriate to a given type of cell and the maximum current intensity associated with it [7].

In addition, heating as well as air conditioning of the interior of the passenger compartment also requires considerable amounts of energy. It has been shown that, depending on the ambient temperature conditions, the use of the air conditioning system may reduce the accessible range by around $18-37 \%[8,9]$.

\section{Current requirements for electric vehicles}

The development of electric cars is mainly relative to the capacity of energy storage equipment. Batteries form the leading element. The lithium-ion battery is one of the promising battery technologies and, therefore, it plays the dominant role in new electric cars (Fig. 3). Arguments such as life cycle, high energy density, high efficiency, low selfdischarge as well as low maintenance costs are usually provided as the main reasons for the use of lithium-ion batteries in electric cars $[10,11]$. However, a rather complex temperature monitoring system [12] as well as charging and discharging cycles [13] are assumed in such conditions.

Even for the case when batteries have high energy density, they generally have a low power density, making them an element with a low efficiency for rapid energy transformations [14]. Therefore, it is beneficial to combine the batteries with another storage element with complementary properties, such as an ultracapacitor (UC), which provides high power density combined with low energy density [15]. Moreover, the degradation of batteries is accelerated when they are subjected to discontinuous or rapidly changing current profiles (e.g. as a result of abrupt acceleration and braking cycles) [16]. However, the use of an ultracapacitor (UC) leads to the slowing of the battery degradation process.

One of the main factors that can limit the popularity of electric cars is related to the limited driving range. An effective solution to this problem is associated with maximization of the energy efficiency of electric vehicles in order to increase their driving range. As regenerative braking forms a key technology for electric vehicles, this area is of constant interest to researchers (Fig. 4) [17, 18].

A system based on single-pedal electric vehicle control was developed in order to further improve conventional regenerative braking systems and their energy recovery capacity. The brake pedal is only employed for emergency braking [19]. 


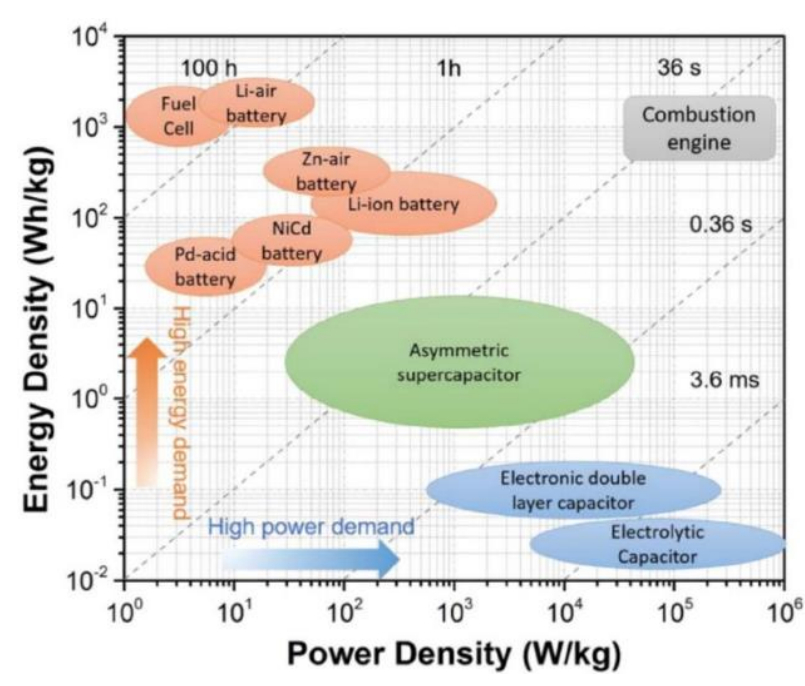

Fig. 3. Ragone plot illustrating the performance of specific power vs specific energy for different electrical energy-storage technologies [11] (times shown in the plot represent discharge times, obtained by dividing the energy density by the power density)
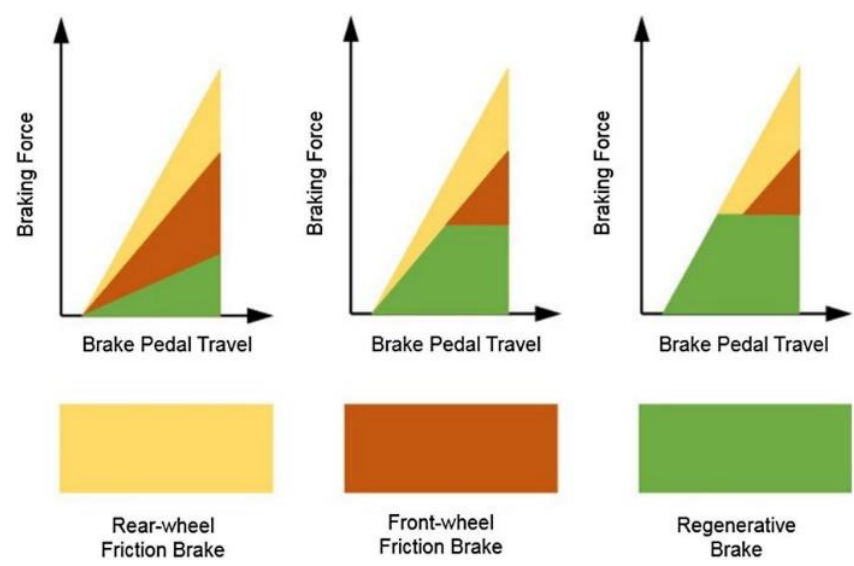

Fig. 4. Three different control strategies applied in regenerative braking process [17]

The simulation results demonstrated that the car deceleration control by one pedal has met the requirements for vehicle braking, and the braking distance complied with safety regulations. The simulated NEDC urban driving cycle performed on a mid-range passenger car showed an energy recovery of $26.12 \%$. Verification of the NEDC cycle on a chassis dynamometer showed a similar level of energy recovery, lower by $0.48 \%$ [20].

\section{Power management systems}

Energy management systems in electric cars form one of the most important and popular areas of research at present. Over the past few decades, several types of energy management strategies have been developed for hybrid cars. These strategies can be classified according to two main categories: one is based on the heuristic concept; the second is based on the theory of optimal control. The first one mainly includes algorithms based on learning rules and fuzzy logic [21, 22]. Initially, energy management strategies were dominated by such algorithms due to their simplicity in implementation. However, such strategies cannot guarantee optimal power distribution between energy sources and consumers. In addition, fuzzy rules and logic require expert knowledge. To solve this problem, the theory of optimal control was originally proposed, including both dynamic programming, developed by R.E. Bellman [23] and the Pontryagin minimum principle (PMP) [24-26]. Over time, mainly due to the fact that the computation time was too long, the real-time control had to be modified. Some researchers have proposed stochastic dynamic programming (SDP) [27] to overcome this problem.

\section{Current directions of research into development of electric vehicles}

The useful parameters of electric vehicles are related to their primary source of energy, that is, batteries. The travel range expected by drivers requires high-capacity batteries. Current lithium-ion batteries are characterized by the quick discharge cycle and thus require frequent recharging. Due to this disadvantage, people are discouraged from electric vehicles.

In order for the batteries to easily meet the requirements presented above, ultracapacitors with excellent parameters, in particular at low temperatures, are installed in cars. Managing the operation of an ultracapacitor with a lithium-ion battery requires the use of a hybrid energy storage system (HESS) with a properly developed management strategy [28].

Regardless of the above, attempts are made to implement solutions, systems that can charge the battery while the vehicle is in motion and extend the driving range without the need to stop for recharging.

Considering the above, the aim of the publication is to review the research carried out using renewable energy sources, such as wind and solar energy, and energy derived from vertical displacement of a car driving on road roughness.

\subsection{Wind energy}

A wind turbine with a vertical axis can be used to utilize wind energy in a car [29]. If such a turbine was installed inside the front grille of a vehicle, the turbine could be applied for generating power. As the vehicle drives, air flows through the vehicle's grille and drives the turbine. There will be variations in the flow rate of air entering the vehicle depending on the vehicle speed. If the vehicle is traveling at a higher speed, the airflow will be greater. The research carried out by Niranjana [30] found that when the vehicle is traveling at a speed of $90 \mathrm{~km} / \mathrm{h}$, the wind turbine is capable of generating $1000 \mathrm{~W}$ of power. Altab Hossain et al. [31], tested a similar turbine for a wind speed of $90 \mathrm{~km} / \mathrm{h}$ and obtained power output of $709 \mathrm{~W}$, and at $72 \mathrm{~km} / \mathrm{h}$, the output would be equal to $567 \mathrm{~W}$.

The study by Niranjana found that the efficiency of a turbine can be increased by modifying its size and blade design. A similar conclusion was also offered by Nikam and Kherde [32] who additionally analyzed wind turbines with a horizontal axis. In turn, Gulve and Barve [33] comparing wind turbines found that those with the vertical axis provide a greater efficiency. On the other hand, Awal et alia [34], examined horizontal axis wind turbines to demonstrate the effect of the use of a diffuser on the volume of power that is generated. 
a)
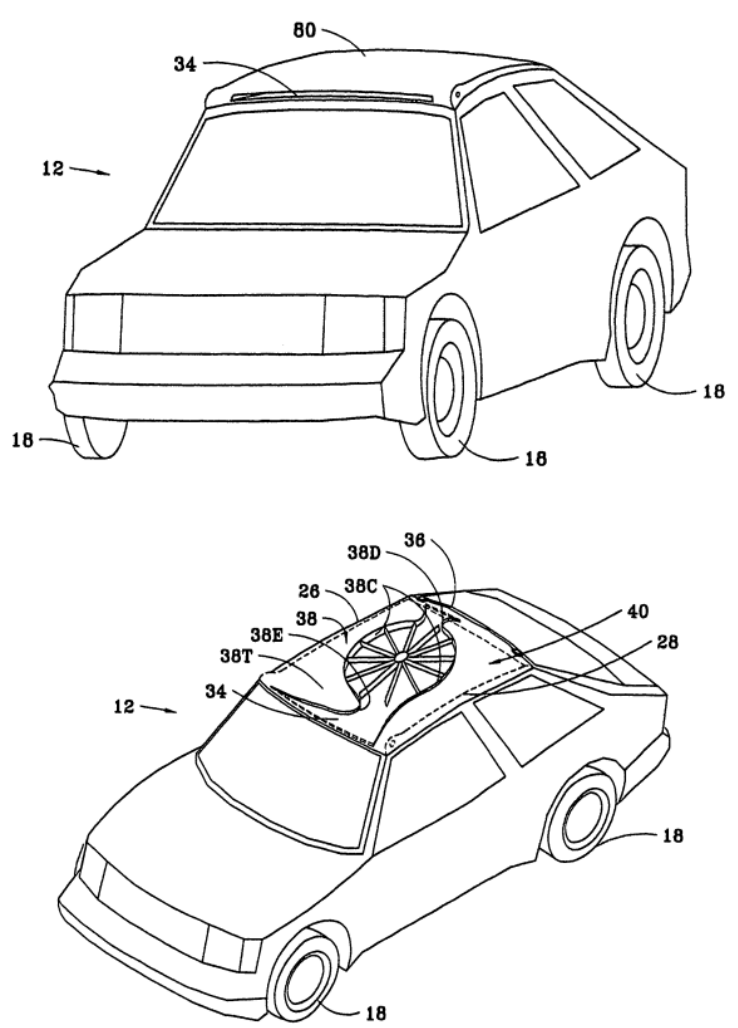

b)
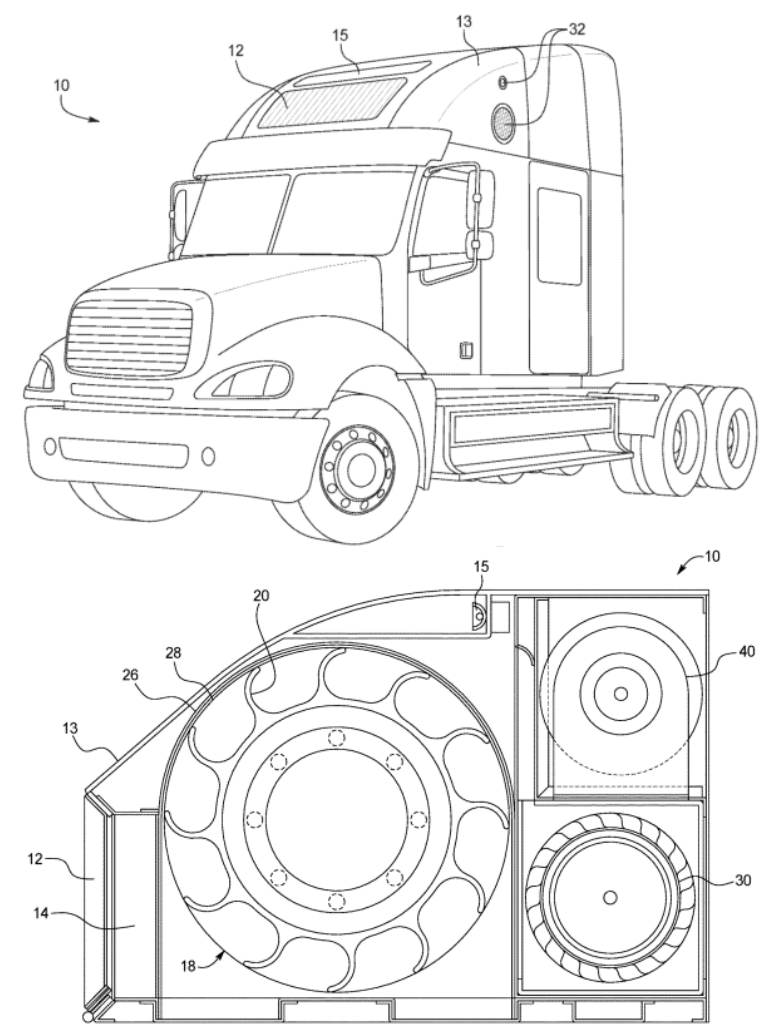

Fig. 5. Systems for harnessing wind energy: a) US Patent 10358038B1 [35], b) US Patent 10655604B1 [36]

A variety of ideas for electricity storage systems using a wind-powered turbine have been presented in the form of patents for many years. The most up-to-date is the system of using wind energy to charge the vehicle's electric battery, regardless of whether the vehicle is parked or in motion. It was presented in the result of research and patent by Peter W. Ripley (Fig. 5a) [35]. In this study, a roof-mounted double vertical wind turbine was proposed that is connected to an electric generator, which could use wind energy both when the vehicle is in motion and when it does not move.

Another current invention of James R. Parker (Fig. 5b) [36] involves a generator and an electrical energy storage system using a wind turbine assisted by the exhaust air system. The vehicle-mounted energy generator and energy storage system includes: an air intake with a shield facing the front of the vehicle through which air enters when the vehicle drives. A cylindrical air rotor assembly including one or more integrated blades positioned such that air flowing through the air inlet applies a positive pressure to the one or more rotor blades that drive one or more generators. One or more batteries are applied to store the energy generated by the rotor assembly.

\subsection{Solar energy}

Despite spectacular results in competitions such as the World Solar Challenge, vehicles that are powered exclusively by the sun do not offer a practical alternative to conventional cars due to significant limitations in maximum power and range. On the other hand, photovoltaics can be an effective and clean additional source of energy for electric vehicles (Fig. 6) [37].

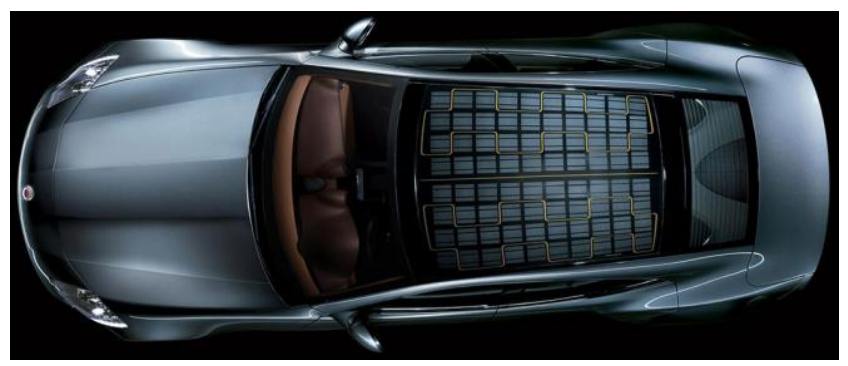

Fig. 6. Solar roof of the KARMA Revero [37]

A power supply system applicable for the cooling of the interior of the vehicle cabin provides a practical idea including simplest form of a solar panel, proposed and tested by Yan, Tseng and Leong [38]. This solution offers the removal of hot air from the car interior that can be replaced with cool fresh air from the outside environment. The assembly consists of a solar cell panel with a capacity of $27 \mathrm{~W}$, four fans and a battery with a capacity of $850 \mathrm{mAh}$. This kit for self-assembly (KIT) weighs less than $1500 \mathrm{~g}$. It has been found that a fully charged battery is capable of driving the fans for approximately 45 minutes. The time obtained may seem very short. However, we should remember that cloudy skies also mean low sun exposure and therefore the need for removing hot air from the cabin is reduced. 
The space available for solar panels in cars is quite limited for stationary applications. It is therefore mandatory to maximize their performance and accurately forecast useful energy production [39]. A quantitative assessment of the contribution of solar energy is needed when carrying out a cost-benefit analysis of the design of a solar powered vehicle. The research carried out in this matter [40] demonstrated that the roof panel of the FIAT Punto passenger car (Fig. 7) reached a maximum output of $165 \mathrm{~W}$ on a sunny summer day, while the panel on the front hood reached a total power of $75 \mathrm{~W}$ (Fig. 8). The efficiency of the modules is influenced by temperature, which reduces the efficiency of the roof panel to $18 \%$ and of the hood panel to $19.8 \%$.

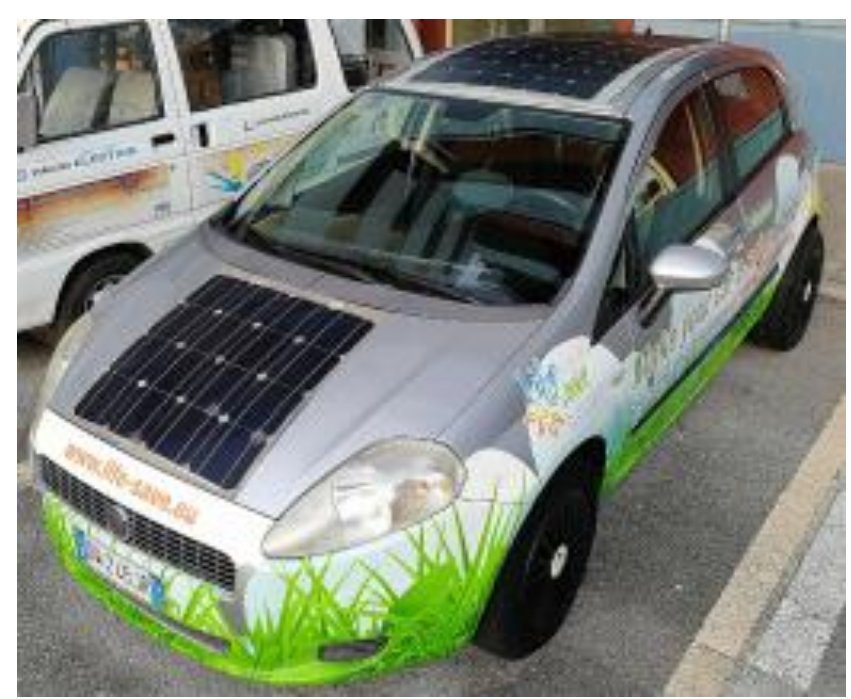

Fig. 7. Hybrid Solar Vehicle prototype [40]

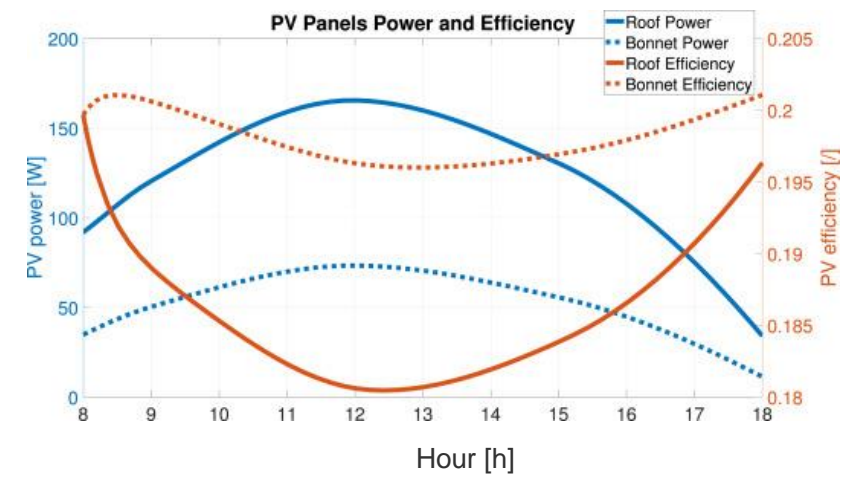

Fig. 8 Power and efficiency of the PV panels during parking on August 5th [40]

The potential benefits of solar energy are clearly visible indeed: it is free and plentiful but there are also limitations such as weather conditions and last but not least is the solar flux density. If solar panels are to be properly designed and utilized, they can generate a part of the total energy needed by a car in particular in the conditions of city driving. Moreover, their economic feasibility in automotive applications appears to be increasingly encouraging, due to the spectacular cost reductions that we have faced in recent decades [41]. In fact, in recent years, more and more attention has been paid to integrating photovoltaics, especially in electric cars $[42,43]$. The energy gain of the photovoltaic system integrated in the vehicle differs from the designs applied in the standard photovoltaics.

This is mainly due to the difference in the intensity of solar radiation on the car roof and the body due to its variable orientation in relation to the sun, as well as its curved shape. Car manufacturers forecast that photovoltaic panels that will have a curved shape to fit the car's bodywork. In the publication [42], a method of assessing the efficiency of photovoltaic panels was developed and a correction factor was proposed that takes into account the curvature of the car body and the irregular distribution of sunlight and shade on the curved surface of car panels. The publication [43] estimated that replacing all classic passenger cars in Japan with hybrid vehicles comprising a photovoltaic module with a rated power of $800 \mathrm{~W}$, that is capable of generating a mean power of $1.8 \mathrm{kWh} /$ day, would reduce $\mathrm{CO}_{2}$ emissions by $63 \%$. To confirm the reliability of this statement, photovoltaic modules were installed on a Toyota Prius test car (Fig. 9) on all possible body surfaces with a total area of $6.8 \mathrm{~m}^{2}$, achieving an average output of $2.1 \mathrm{kWh} /$ day.

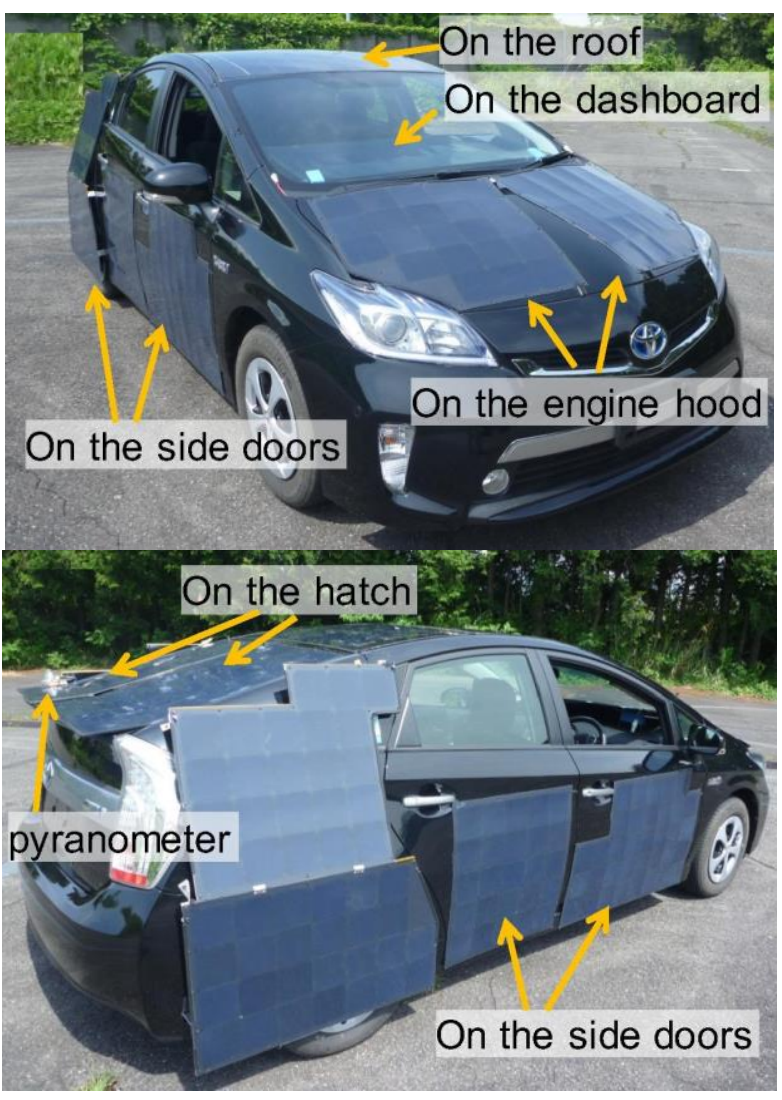

Fig . 9 Test vehicle Toyota Prius [43]

The study reported in [44] indicates that a typical roof area (1.7-2.0 $\left.\mathrm{m}^{2}\right)$ of a medium-class car, comprising a photovoltaic panels with a power $(340-500 \mathrm{~W})$, can yield an additional driving range per year in the range from 1900 up to $3,400 \mathrm{~km}$ (Table 1 ). Fig. 10 shows the range of the potential offered by the photovoltaics used on selected cars. The presented data does not take into account the conditions when the battery is fully charged when solar energy is not available. 
Table 1. Investigated types of electric vehicles and selected parameters corresponding to them [44]

\begin{tabular}{|c|c|c|c|c|c|c|c|}
\hline Vehicle & $\begin{array}{l}\text { Consumption } \\
{[\mathrm{kWh} / 100 \mathrm{~km}]}\end{array}$ & $\begin{array}{c}\text { Battery } \\
\text { capacity } \\
{[\mathrm{kWh}]}\end{array}$ & $\begin{array}{c}\text { Range } \\
{[\mathrm{km}]}\end{array}$ & $\begin{array}{c}\text { Roof area } \\
{\left[\mathrm{m}^{2}\right]}\end{array}$ & $\begin{array}{c}\text { Potential } \\
\text { solar power } \\
\text { [W] }\end{array}$ & $\begin{array}{c}\text { Yearly energy } \\
\text { yield } \\
{[\mathrm{kWh}]}\end{array}$ & $\begin{array}{c}\text { Yearly solar } \\
\text { driving range } \\
{[\mathrm{km}]}\end{array}$ \\
\hline Audi e-tron & 24,0 & 95 & 436 & 2,3 & 460 & 495 & 2063 \\
\hline BYD e6 & 21,5 & 80 & 400 & 2,2 & 440 & 473 & 2200 \\
\hline Chevrolet Bolt EV & 16,0 & 60 & 380 & 2,0 & 400 & 430 & 2688 \\
\hline Hyundai Ioniq Electric & 13,8 & 38,2 & 311 & 2,2 & 440 & 473 & 3428 \\
\hline Daimler EQC & 23,5 & 80 & 390 & 2,1 & 420 & 452 & 1923 \\
\hline Nissan Leaf & 20,0 & 40 & 270 & 1,8 & 360 & 387 & 1935 \\
\hline Tesla Model 3 & 16,0 & 75 & 560 & 2,5 & 500 & 538 & 3363 \\
\hline Volkswagen ID3 & 14,0 & 77 & 550 & 1,9 & 380 & 409 & 2921 \\
\hline BMW i3 & 13,1 & 37,9 & 359 & 1,9 & 380 & 409 & 3122 \\
\hline Renault ZOE & 17,7 & 52 & 386 & 1,7 & 340 & 366 & 2068 \\
\hline
\end{tabular}

The latest development takes the form of Lightyear One (Fig. 11), solar powered car with a range of $725 \mathrm{~km}$. A photovoltaic module with an area of $5 \mathrm{~m}^{2}$ and rated power of $1075 \mathrm{~W}$ was installed on the vehicle [45]. The range of the vehicle is influenced by its energy consumption, which results from the low drag coefficient equal to 0.2 , lightweight construction, including the battery, and the innovative Turanza Eco tires developed by Bridgestone [46] with very low rolling resistance (Fig. 12).

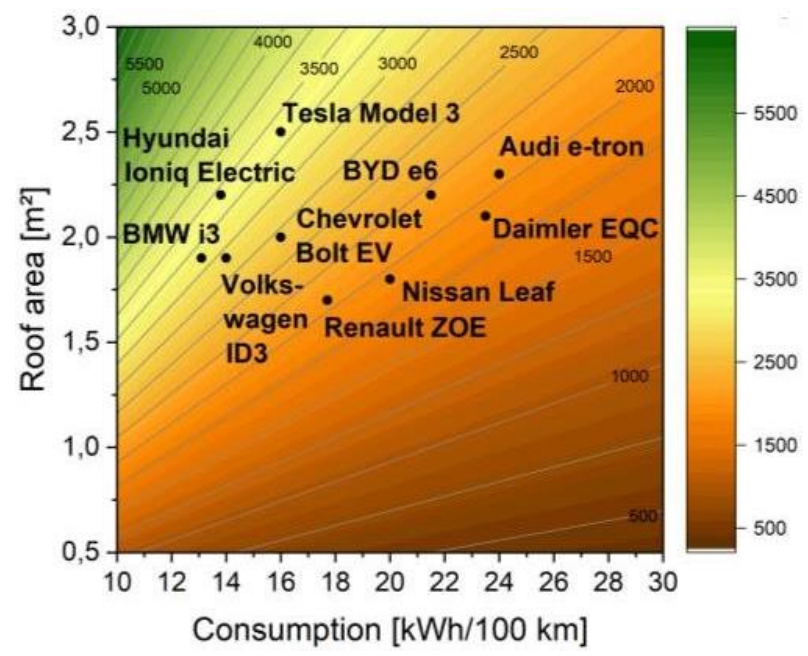

Fig. 10. Potential solar range for different electric vehicles depending on available horizontal roof area and consumption [44]

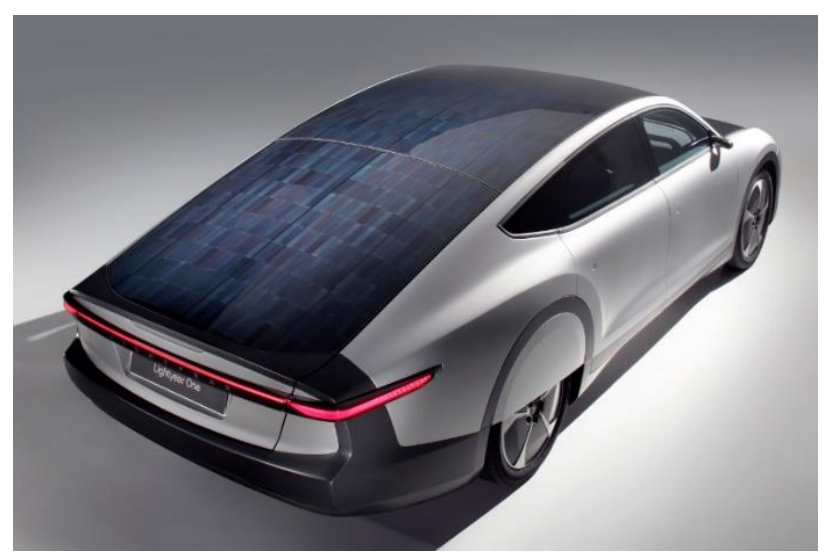

Fig. 11. Lightyear One - Solar Electric Powered Car [45]

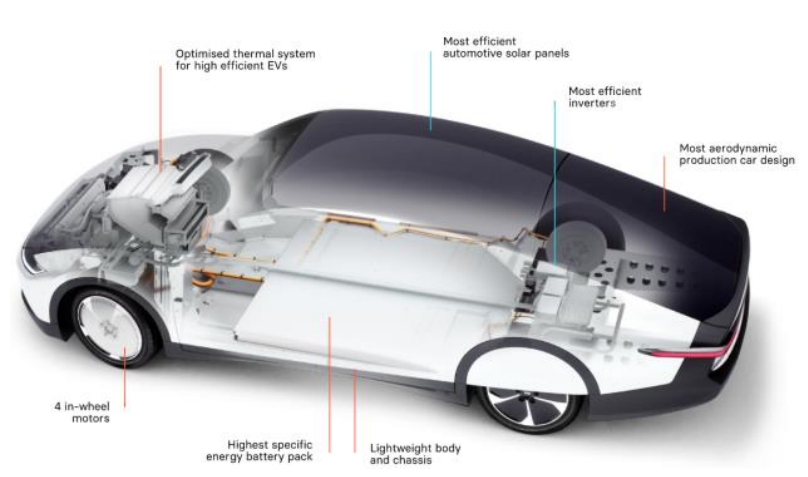

Fig. 12. Lightyear One - main components [45]

\subsection{Energy of damper vibration}

Nearly all cars apply dampers to absorb vibrations from road roughness. Energy in conventional shock absorbers is dissipated in the form of heat and is not utilized in any way. The energy recovery system not only recovers vibration energy, but also converts it into electrical energy that can be stored in batteries as a source of power. Since the idea of energy recovery was intensified in the last century, energy efficiency has gained in importance in the automotive industry, the research of suspensions with energy recovery systems was revived to [47].

The publication [48] contains an outline of a suspension system with energy recovery with an energy efficiency of $55 \%$ found while driving on the road with a intermediateclass surface quality, at a speed of $60 \mathrm{~km} / \mathrm{h}$. In selected passenger cars, off-road vehicles and trucks, power was obtained with the following values: $105.2 \mathrm{~W}, 384 \mathrm{~W}$ and $1152 \mathrm{~W}$, respectively.

The publication [49] presents a system with the mean efficiency of $40 \%$, and the maximum $52 \%$. The power recorded in the system was $270 \mathrm{~W}$.

A similar effect in terms of the amount of power recovered by a vehicle in urban traffic can be found in the publication [50]. The obtained power ranges from 71.3-387 W.

Simulation and bench tests carried out in 2019-2020, on the basis of available technologies and control techniques, did not demonstrate a significant improvement in the efficiency of the suspension with energy recovery [51-54]. For vehicles driving on the road, the surface quality of the middle class ranges from $100 \mathrm{~W}$ to $400 \mathrm{~W}$. 
There is agreement in the above-mentioned tests that the damping characteristics and the level of energy regeneration in the suspension system with energy recovery are mainly influenced by the damping force, road roughness, vehicle speed, suspension stiffness, tire stiffness, wheels and wheel mass.

The up-to-date active suspension systems require energy for the power supply and control the actuator assembly. Thus, one of the most interesting goals to be achieved by the researchers $[55,56]$ involved the achievement of such efficiency of the energy recuperation of suspension vibrations that did not only meet the demand for energy consumption by the active suspension but also offered some excess.

\section{Conclusion}

Electric cars will be the future of automotive industry. We can note that car manufacturers now add more and more electric vehicles to their range of vehicles. Everyone works on electric vehicles, from reputable manufacturers to the ones that create new brands. The era of modern electric vehicles has only just begun. New electric vehicles have greater capacities, cheaper, safer and more reliable.

In Poland, in recent years, many stations have been built, but they are not well equipped. Only a small number of stations have chargers for quick charging. This is important, especially for high-powered cars. Then the charging time using the DC charger is significantly longer. Such situation has a negative impact on the increased sales of electric cars in Poland [57].

We are facing conditions in which electric vehicles that offer a range exceeding $200 \mathrm{~km}$ on a single charge start to become common, with a note that the latest Tesla Model $\mathrm{S}$ Long Range Plus claims to offer a maximum range of 550 $\mathrm{km}$. Electric car makers are eagerly awaiting a battery breakthrough that will improve vehicle range as well as the battery life itself. The start-up company Innolith was developing a high-density lithium-ion battery $(1000 \mathrm{Wh} / \mathrm{kg})$ that could solve both of these problems [58].
The latest patents in terms of weight reduction and battery performance include the developments of lithiumsulfur cells. These are fully compostable biodegradable organic batteries that will not only offer an adequate environmental option but will also charge them very quickly. They are also significantly lighter. The newest lithiumsulfur (Li-S) battery offered on the market offers an energy density of $2567 \mathrm{Wh} / \mathrm{kg}$, reflecting up to a three to fivefold increase in performance over current Lithium-Ion (Li-Ion) design counterparts [59, 60].

Electric vehicles design involving lightweight materials and the use of composites will undoubtedly play their part. However, this can be a much greater role than simply reducing vehicle weight, but also improving safety in case of accidents, driving dynamics and overall vehicle strength. Particular proposals in terms of weight reduction include increasingly lighter composite materials used in battery housings. Additionally, they play an important role as insulation, as they perform better than classic materials, maintaining the batteries at their operating temperature (thermal equilibrium state) [61].

The use of renewable energy sources such as wind and solar energy forms some of the issues that are frequently considered by research centers with the purpose of improving the energy balance of electric cars. The proposed solution offers measurable benefits and is only a matter of assessing the rationale and economic justification of their use by a specific manufacturer of electric cars.

The same question applies to the use of energy derived from vertical displacements of a vehicle in motion due to road roughness. However, it should be remembered that the amount of energy that can be recovered depends on the degree of roughness of the road surface and the speed of the car. If we assume that the road infrastructure will be characterized by better quality of road surfaces over time, the use of a depreciation system with energy recovery may turn out to be ineffective.

\section{Bibliography}

[1] Electric vehicle market - global opportunity analysis and industry forecast, 2020-2027, 2020.

[2] SKOURAS, T., GKONIS, P., ILIAS, C. et al. Electrical vehicles: current state of the art, future challenges, and perspectives. Clean Technologies. 2019, 2(1), 1-16. https://doi.org/10.3390/cleantechnol2010001

[3] SHARMA, S., PANWAR, A.K., TRIPATHI, M.M. Storage technologies for electric vehicles. Journal of Traffic and Transportation Engineering (English Edition). 2020, 7(3), 340-361. https://doi.org/10.1016/j.jtte.2020.04.004

[4] BARKENBUS, J.N. Prospects for electric vehicles. Sustainability. 2020, 12(14), 5813.

https://doi.org/10.3390/su12145813

[5] Where The Energy Goes: Electric Cars, 2020.

[6] THOMAS, J. Drive cycle powertrain efficiencies and trends derived from EPA vehicle dynamometer results. SAE International Journal of Passenger Cars - Mechanical Systems. 2014, 7(4), 1374-1384. https://doi.org/10.4271/2014-01-2562

[7] LECHOWICZ, A., AUGUSTYNOWICZ, A. Problems of electricity and thermal management of an exemplary electric

vehicle. Maszyny Elektryczne - Zeszyty Problemowe. 2018, 3(119), 43-47

[8] XIE, Y., ZHAOMING, L., KUINING, L. et al. An improved intelligent model predictive controller for cooling system of electric vehicle. Applied Thermal Engineering. 2021, 182, 116084 .

https://doi.org/10.1016/j.applthermaleng.2020.116084

[9] PAN, L., LIU, C., ZHANG, Z. et al. Energy-saving effect of utilizing recirculated air in electric vehicle air conditioning system. International Journal of Refrigeration. 2019, 102, 122-129. https://doi.org/10.1016/j.ijrefrig.2019.03.018

[10] MIAO, Y., HYNAN, P., VON JOUANNE, A. et al. Current Li-Ion battery technologies in electric vehicles and opportunities for advancements. Energies. 2019, 12(6), 1074. https://doi.org/10.3390/en12061074

[11] SHAO, Y., EL-KADY, M.F., SUN, J. et al. Design and mechanisms of asymmetric supercapacitors. Chemical Reviews. 2018, 118(18), 9233-9280. https://doi.org/10.1021/acs.chemrev.8b00252

[12] WU, S., XIONG, R., LI, H. et al. The state of the art on preheating lithium-ion batteries in cold weather. Journal of 
Energy Storage. 2020, 27, 101059.

https://doi.org/10.1016/j.est.2019.101059

[13] SHEN, S., SADOUGHI, M., CHEN, X. et al. A deep learning method for online capacity estimation of lithium-ion batteries. Journal of Energy Storage. 2019, 25, 100817. https://doi.org/10.1016/j.est.2019.100817

[14] SARLIOGLU, B., MORRIS, C.T., HAN, D. et al. Driving toward accessibility: a review of technological improvements for electric machines, power electronics, and batteries for electric and hybrid vehicles. IEEE Industry Applications Magazine. 2017, 23(1), 14-25.

https://doi.org/10.1109/MIAS.2016.2600739

[15] SATPATHY, S., DAS, S., BHATTACHARYYA, B.K. How and where to use super-capacitors effectively, an integration of review of past and new characterization works on super-capacitors. Journal of Energy Storage. 2020, 27, 101044. https://doi.org/10.1016/j.est.2019.101044

[16] JAFARI, M., GAUCHIA, A., ZHAO, S. et al. Electric vehicle battery cycle aging evaluation in real-world daily driving and vehicle-to-grid services. IEEE Transaction Transportation Electrification. 2017, 4(1), 122-134. https://doi.org/10.1109/TTE.2017.2764320

[17] QIU, C., WANG, G. New evaluation methodology of regenerative braking contribution to energy efficiency improvement of electric vehicles. Energy Conversion Management. 2016, 119, 389-398. https://doi.org/10.1016/j.enconman.2016.04.044

[18] KROPIWNICKI, J., FURMANEK, M. Analysis of the regenerative braking process for the urban traffic conditions. Combustion Engines. 2019, 178(3), 203-207.

https://doi.org/10.19206/CE-2019-335

[19] HONGWEN, H., CHEN, W., HUI, J. A single-pedal regenerative braking control strategy of accelerator pedal for electric vehicles based on adaptive fuzzy control algorithm. Energy Procedia. 2018, 152, 624-629.

https://doi.org/10.1016/j.egypro.2018.09.221

[20] LIU, W., QI, H., LIU, X. et al. Evaluation of regenerative braking based on single-pedal control for electric vehicles. Frontiers of Mechanical Engineering. 2020, 15, 166-179. https://doi.org/10.1007/s11465-019-0546-X

[21] LI, Q., CHEN, W., LI, Y. et al. Energy management strategy for fuel cell/battery/ultracapacitor hybrid vehicle based on fuzzy logic. International Journal of Electrical Power and Energy Systems. 2012, 43(1), 514-525. https://doi.org/10.1016/j.ijepes.2012.06.026

[22] LI, D., XU, B., TIAN, J. et al. Energy management strategy for fuel cell and battery hybrid vehicle based on fuzzy logic. Processes. 2020, 8(8), 882. https://doi.org/10.3390/PR8080882

[23] LIN, C.C., PENG, H., GRIZZLE, J.W. et al. Power management strategy for a parallel hybrid electric truck. IEEE Transactions on Control Systems Technology. 2003, 11(6), 839-849. https://doi.org/10.1109/TCST.2003.815606

[24] SERRAO, L., RIZZONI, G. Optimal control of power split for a hybrid electric refuse vehicle. Proceedings of the American Control Conference. 2008, 4498-4503. https://doi.org/10.1109/ACC.2008.4587204

[25] CHASSE, A., SCIARRETTA, A. Supervisory control of hybrid powertrains: An experimental benchmark of offline optimization and online energy management. Control Engineering Practice. 2011, 19(11), 1253-1265. https://doi.org/10.1016/j.conengprac.2011.04.008

[26] KIM, N., CHA, S.W., PENG, H. Optimal equivalent fuel consumption for hybrid electric vehicles. IEEE Transactions on Control Systems Technology. 2012, 20(3), 817-825.

https://doi.org/10.1109/TCST.2011.2123099

[27] LIN, C.C., PENG, H., GRIZZLE, J.W. A stochastic control strategy for hybrid electric vehicles. Proceedings of the 2004 American Control Conference. 2004, 5, 4710-4715. https://doi.org/10.23919/acc.2004.1384056

[28] XIONG, R., DUAN, Y., CAO, J. et al. Battery and ultracapacitor in-the-loop approach to validate a real-time power management method for an all-climate electric vehicle. Applied Energy. 2018, 217, 153-165. https://doi.org/10.1016/j.apenergy.2018.02.128

[29] SUN, X., CHEN, Y., CAO, Y. et al. Research on the aerodynamic characteristics of a lift drag hybrid vertical axis wind turbine. Advances in Mechanical Engineering. 2016, 8(1), 1-11. https://doi.org/10.1177/1687814016629349

[30] NIRANJANA, S.J. Power generation by vertical axis wind turbine. International Journal of Emerging Research Management \&Technology. 2015, 4(7), 1-7. http://matjournals.in/index.php/JoADD/article/view/1304

[31] HOSSAIN, A., IQBAL, A.K.M.P., RAHMAN, A. et al. Design and development of A 1/3 scale vertical axis wind turbine for electrical power generation. Journal of Urban and Environmental Engineering. 2007, 1(2), 53-60. https://doi.org/10.4090/juee.2007.v1n2.053060.

[32] NIKAM, D.A., KHERDE, S.M. Literature review on design and development of vertical axis wind turbine blade. International Journal of Engineering Research and Applications. 2015.

https://www.ijera.com/special_issue/NCERT-Nov2015/156161.pdf

[33] GULVE, P., BARVE, S.B. Design and construction of vertical axis wind turbine. International Journal of Mechanical Engineering and Technology. 2014, 5(10), 148-155.

[34] AWAL, M.R., JUSOH, M., SAKIB, M.N. et al. Design and implementation of vehicle mounted wind turbine. ARPN Journal of Engineering and Applied Sciences. 2015, 10(19), 8699-8706. http://www.arpnjournals.com

[35] RIPLEY, P. Wind Turbine for Electric Car, US 10358038B1, July 2019.

[36] PARKER, J. Power evacuated, barrel impellered, pneumatic electric generating and storage system and methods (PEBI system), US10655604B1, May 2020.

[37] a2-solar Advanced and Automotive Solar Systems GmbH, 2021. www.a2-solar.com

[38] YAN, Y.-A., TSENG, C.-Y., LEONG, J.C. Feasibility of solar powered cooling device for electric car. Energy Procedia. 2012, 14, 887-892,

https://doi.org/10.1016/j.egypro.2011.12.1028

[39] ARAKI, K., JI, L., KELLY, G. et al. To do list for research and development and international standardization to achieve the goal of running a majority of electric vehicles on solar energy. Coatings. 2018, 8(7), 251.

https://doi.org/10.3390/coatings8070251

[40] TIANO, F.A., RIZZO, G., MARINO, M. et al. Evaluation of the potential of solar photovoltaic panels installed on vehicle body including temperature effect on efficiency. eTransportation. 2020, 5, 100067. https://doi.org/10.1016/j.etran.2020.100067

[41] Renewable power generation costs in 2019, International Renewable Energy Agency, Abu Dhabi 2020. https://www.irena.org/

[42] ARAKI, K., OTA, Y., YAMAGUCHI, M. Measurement and modeling of $3 \mathrm{D}$ solar irradiance for vehicle-integrated photovoltaic. Applied Sciences. 2020, 10(3), 872, https://doi.org/10.3390/app10030872

[43] MASUDA, T., ARAKI, K., OKUMURA, K. et al. Static concentrator photovoltaics for automotive applications. Solar Energy. 2017, 146, 523-531.

https://doi.org/10.1016/j.solener.2017.03.028

[44] HEINRICH, M., KUTTER, C., BASLER, F. Potential and 
challenges of vehicle integrated photovoltaics for passenger cars. 37th European Photovoltaic Solar Energy Conference and Exhibition. 2020, 1695-1700.

https://doi.org/10.4229/EUPVSEC20202020-6DO.11.1

[45] BILLINGTON, J. Bridgestone creates special 'EV eco tires' for solar-powered electric car with $725 \mathrm{~km}$ range. Electric \& hybrid vehicle technology international. April 23, 2021. https://www.electrichybridvehicletechnology.com/

[46] Bridgestone and lightyear combine forces for the world's first long-range solar electric powered car. BridgestoneAmericas.com. April 22, 2021.

https://www.bridgestoneamericas.com/

[47] LV, X., JI, Y., ZHAO, H. et al. Research review of a vehicle energy-regenerative suspension system. Energies. 2020, 13(2), 441. https://doi.org/10.3390/en13020441

[48] ZHANG, Y., GUO, K., WANG, D. et al. Energy conversion mechanism and regenerative potential of vehicle suspensions. Energy. 2017, 119, 961-970.

https://doi.org/10.1016/j.energy.2016.11.045

[49] SALMAN, W., QI, L., ZHU, X. et al. A high-efficiency energy regenerative shock absorber using helical gears for powering low-wattage electrical device of electric vehicles. Energy. 2018, 159, 361-372.

https://doi.org/10.1016/j.energy.2018.06.152

[50] SHI, D., PISU, P., CHEN, L. et al. Control design and fuel economy investigation of power split HEV with energy regeneration of suspension. Applied Energy. 2016, 182, 576589. https://doi.org/10.1016/j.apenergy.2016.08.034

[51] BOWEN, L., VINOLAS, J., OLAZAGOITIA, J.L. Design and potential power recovery of two types of energy harvesting shock absorbers. Energies. 2019, 12(24), 4710. https://doi.org/10.3390/en12244710

[52] LI, S., XU, J., PU, X. et al. A novel design of a damping failure free energy-harvesting shock absorber system. Mechanical Systems Signal Processing. 2019, 132, 640-653. https://doi.org/10.1016/j.ymssp.2019.07.004

[53] LONG, G., DING, F., ZHANG, N. et al. Regenerative active suspension system with residual energy for in-wheel motor driven electric vehicle. Applied Energy. 2020, 260, 114180. https://doi.org/10.1016/j.apenergy.2019.114180

[54] ZHANG, R., ZHAO, L., QIU, X. et al. A comprehensive comparison of the vehicle vibration energy harvesting abilities of the regenerative shock absorbers predicted by the quarter, half and full vehicle suspension system models. Applied Energy. 2020, 272, 115180.

https://doi.org/10.1016/j.apenergy.2020.115180

[55] LIU, J., LI, X., ZHANG, X. et al. Modeling and simulation of energy-regenerative active suspension based on BP neural network PID control. Shock and Vibration. 2019, 2019, 8. https://doi.org/10.1155/2019/4609754

[56] IQBAL, M.Y., WU, Z., TIE, W. et al. High-efficiency energy harvesting by using hydraulic electromagnetic regenerative shock absorber. Mechanisms and Machine Science. 2021, 105, 276-294.

https://doi.org/10.1007/978-3-030-75793-9_28

[57] MACIEJEWSKA, M., FUĆ, P., KARDACH, M. Analysis of electric motor vehicles market. Combustion Engines. 2019, 179(4), 169-175. https://doi.org/10.19206/ce-2019-428.

[58] AGRAWAL, M., RAJAPATEL, M.S. Global perspective on electric vehicle 2020. International Journal of Engineering Research \& Technology. 2020, 9(1), 8-11. https://doi.org/10.17577/IJERTV9IS010005

[59] HONG, H., MOHAMAD, N.A.R.C., CHAE, K. et al. The lithium metal anode in Li-S batteries: challenges and recent progress. Journal of Materials Chemistry A. 2021, 9(16), 10012-10038. https://doi.org/10.1039/d1ta01091c

[60] LI, Y., GUO, S. Material design and structure optimization for rechargeable lithium-sulfur batteries. Matter. 2021, 4(4), 1142-1188. https://doi.org/10.1016/j.matt.2021.01.012

[61] RAMASWAMY, K., O'HIGGINS, R.M., LYONS, J. et al. An evaluation of the influence of manufacturing methods on interlocked aluminium-thermoplastic composite joint performance. Composites Part A: Applied Science and Manufacturing. 2021, 143, 106281. https://doi.org/10.1016/j.compositesa.2021.106281

Andrzej Augustynowicz, DSc., DEng. - Opole
University of Technology.
e-mail: A.Augustynowicz@po.opole.pl

